\title{
Tagalog Language
}

National Cancer Institute

\section{Source}

National Cancer Institute. Tagalog Language. NCI Thesaurus. Code C154164.

An Austronesian language spoken as a first language by a quarter of the population of the Philippines and as a second language by the majority. 